\title{
Dyschromatosis Symmetrica Hereditaria
}

National Cancer Institute

\section{Source}

National Cancer Institute. Dyschromatosis Symmetrica Hereditaria. NCI Thesaurus.

Code C118435.

A rare, autosomal dominant inherited disorder caused by heterozygous mutation in the DSRAD gene. Most cases have been reported from countries in East Asia. It is characterized by the presence of hyperpigmented and hypopigmented macules on the dorsal aspect of the extremities and face. 